\title{
ENDOGLUCANASE PRODUCTION BY ENDOPHYTIC FUNGI ISOLATED FROM Vitis labrusca L. WITH PEANUT HULL AND SAWDUST AS SUBSTRATES
}

\author{
PRODUÇÃO DE ENDOGLUCANASE POR FUNGOS ENDOFÍTICOS ISOLADOS DE \\ Vitis labrusca L. UTILIZANDO CASCA DE AMENDOIM E SERRAGEM COMO \\ SUBSTRATOS
}

\begin{abstract}
Aretusa Cristina FELBER ${ }^{1}$; Vânia SPECIAN ${ }^{1}$; Ravely Casarotti ORLANDELLI²; Alessandra Tenório COSTA ${ }^{3}$; Julio Cesar POLONIO ${ }^{4}$; Káthia Socorro Mathias MOURÃO5; João Alencar PAMPHILE ${ }^{6}$

1. Doutora em Biologia das Interações Orgânicas pelo Programa de Pós-Graduação em Biologia Comparada da Universidade Estadual de Maringá, UEM, Maringá, PR, Brasil; 2. Professora Colaboradora, Doutora, Colegiado de Ciências Biológicas, Universidade Estadual do Paraná, UNESPAR, Paranavaí, PR, Brasil. 3. Doutora em Ciências Biológicas (Genética) pelo Programa de Pós-Graduação em Ciências Biológicas (Genética), Instituto de Biociências de Botucatu, Universidade Estadual Paulista "Júlio de Mesquita Filho", UNESP, Botucatu, SP, Brasil. 4. Doutorando em Biotecnologia Ambiental-UEM, Maringá, PR, Brasil; 5. Professora Associada, Doutora, Departamento de Biologia-UEM, Maringá, PR, Brasil; 6. Professor Associado, Doutor, Departamento de Biotecnologia, Genética e Biologia Celular-UEM, Maringá, PR, Brasil. japamphile@gmail.com.
\end{abstract}

\begin{abstract}
Endoglucanases are enzymes widely employed in different industrial fields, albeit with high production costs. Studies on new microbial sources and low-cost substrates are highly relevant, including those on agro-industrial. Current analysis evaluates peanut hull (PH) and sawdust (SD) as substrates for submerged cultures of 14 endophytic fungi isolated from grapevine (Vitis labrusca L.) cultivars Bordô and Concord. Endophytes were grown on a carboxymethylcellulose (CMC) medium and the cup plate assay showed that eight strains (belonging to genera Cochliobolus, Diaporthe, Fusarium and Phoma) had positive results: enzymatic halos ranged from $10.8 \pm 0.02$ to $15.5 \pm 0.07 \mathrm{~mm}$ in diameter. Diaporthe sp. strains (GenBank accession codes KM362392, KM362368 and KM362378) and Fusarium culmorum KM362384 were highlighted as the most promising sources. Further, PH and SD as substrates for the fermentation of these fungi were evaluated by the cup plate assay and endoglucanase activity assay. Highest halo diameters were obtained for Diaporthe sp. KM362392: 16.1 $\pm 0.01 \mathrm{~mm}(\mathrm{CMC}), 14.5 \pm 0.01 \mathrm{~mm}(\mathrm{PH})$ and $14.7 \pm 0.03 \mathrm{~mm}(\mathrm{SD})$. The fungus also presented the highest levels of endoglucanase activity: analysis of variance revealed that CMC $(3.52 \pm 0.98 \mu \mathrm{mol} / \mathrm{min}), \mathrm{PH}(2.93 \pm 0.23 \mu \mathrm{mol} / \mathrm{min})$ and SD $(3.26 \pm 0.38 \mu \mathrm{mol} / \mathrm{min})$ were similarly efficient as substrates. Results deepen knowledge on $V$. labrusca endophytes that may be endoglucanase sources, even though further optimizations in submerged cultures with PH and SD should be undertaken to increase the enzymatic production from these wastes.
\end{abstract}

KEYWORDS: Cellulase. Microbial enzymes. Endophytes. Agro-industrial wastes. Submerged fermentation.

\section{INTRODUCTION}

Endophytic fungi colonize intra- or intercellular spaces of healthy plant tissues (FELBER et al., 2016; STONE et al., 2000) without causing any apparent damage; they are ubiquitous organisms found inside all plants (RODRIGUEZ et al., 2009). During their long coexistence process with host plants, these fungi developed important characteristics to maintain a stable symbiosis. Since cellulases hydrolyze the plant cell wall during colonization by microbial endophytes (DUTTA et al., 2014), there is a great interest in endophytic sources of cellulase for industrial application. In fact, the search of microbial enzymes has already detected several endophytic sources of hydrolytic enzymes, as recently reported by Fouda et al. (2015), Orlandelli et al. $(2015,2017 \mathrm{a})$ and Ribeiro et al. (2018).

Cellulolytic enzymes form a complex of three groups that catalyze cellulose hydrolysis to glucose: (1) exoglucanases, including 1,4- $\beta$-Dglucan glucanohydrolases (EC 3.2.1.74) and 1,4- $\beta$ D-glucan cellobiohydrolases (EC 3.2.1.91); (2) endoglucanases or 1,4- $\beta$-D-glucan-4glucanohydrolases (EC 3.2.1.4); (3) $\beta$-glucosidases or $\beta$-glucoside glucohydrolases (EC 3.2.1.21). Exoglucanases act on the reducing or non-reducing ends of cellulose polysaccharide chains and release glucose or cellobiose as major products. 
Endoglucanases cut randomly at internal amorphous sites in the cellulose polysaccharide chain, generating oligosaccharides, whereas $\beta$-glucosidases hydrolyze soluble cellodextrin and cellobiose to glucose (LYND et al., 2002).

Dollar-wise, cellulases represent the third largest industrial enzyme worldwide. However, if, in the future, ethanol from lignocellulosic biomass through the enzymatic route becomes a major transportation fuel, these enzymes may occupy the largest volume of industrial enzymes (SINGHANIA et al., 2013). In particular, endoglucanases have a great potential application in textile and detergent industries, paper recycling, juice extraction, animal feed additives and renewable energy (LIN et al., 2016). The main disadvantage is that cellulases have high production costs. However, industrial wastes may replace the cellulose as substrate, obtaining low-cost enzymes.

Large amount of wastes is annually generated by food, agricultural and forestry industries, causing a serious disposal issue. For instance, about $222 \mathrm{millions} / \mathrm{m}^{3}$ of waste from the lumber industry are generated worldwide and the peanut production exceeds 13 million tons/year (FOOD AND AGRICULTURE ORGANIZATION OF THE UNITED NATIONS, 2014), mostly discarded as waste.

Fungal cellulase researches mainly focus on Fusarium solani, Penicillium pinophilium, Sporotrichum pulverulentum, Trichoderma reesei and Trichoderma viride strains (McKELVEY; MURPHY, 2011). Only scanty data in the literature report endophytes Alternaria, Bipolaris, Cochliobolus, Diaporthe, Fusarium and Phoma as cellulase sources (BEZERRA et al., 2015; CHRISTAKOPOULOS et al., 1995; LUMYONG et al., 2002; PENG; CHENG, 2007). The biosynthesis of microbial products is affected by culture medium composition and cultivation conditions (ELISASHVILI, 2012). Further studies under different culture conditions are necessary to provide an in-depth knowledge on endophytic strains that may be enzymatic sources. This study aimed to compare the use of carboxymethylcellulose, peanut hull and sawdust as substrates for the endoglucanase production by Vitis labrusca L. endophytes.

\section{MATERIAL AND METHODS}

\section{Endophytic fungi}

Fourteen fungal strains of genera Alternaria, Bipolaris, Cochliobolus, Diaporthe, Fusarium and Phoma (Table 1) were used. Fungi were isolated from healthy leaves of Bordô and Concord cultivars of $V$. labrusca (FELBER et al., 2016) and belong to the fungal culture collection of the Laboratorio de Biotecnologia Microbiana, Universidade Estadual de Maringá, Maringá PR Brazil. Molecular identification was based on the sequencing of ITS15.8S-ITS2 region of rDNA. Sequences were deposited in the GenBank database (FELBER et al., 2016).

\section{Agro-industrial wastes}

Peanut hull $(\mathrm{PH})$, obtained from local vendors in Maringá PR Brazil, in the form of food and beverage production wastes, was blended and sieved to obtain 1-mm particles. Sawdust (SD) was obtained from the local lumber industry and preserved in its original size.

\section{Submerged fermentation}

All endophytes were previously grown in Petri dishes with potato dextrose agar medium (SMITH; ONIONS, 1983), at $28 \pm 2^{\circ} \mathrm{C}$, for seven days. Three 5-mm mycelial plugs of each fungus were transferred to $125-\mathrm{mL}$ Erlenmeyer flasks containing $50 \mathrm{~mL}$ of Manachini's solution (MANACHINI et al., 1987), comprising $2 \mathrm{~g} / \mathrm{L}$ $\mathrm{KH}_{2} \mathrm{PO}_{4}, 1 \mathrm{~g} / \mathrm{L}\left(\mathrm{NH}_{4}\right)_{2} \mathrm{SO}_{4}, 0.1 \mathrm{~g} / \mathrm{L} \mathrm{MgSO}_{4} .7 \mathrm{H}_{2} \mathrm{O}$, $0.9 \mathrm{~g} / \mathrm{L} \mathrm{Na} \mathrm{HPO}_{4} \cdot 2 \mathrm{H}_{2} \mathrm{O}, 1 \mathrm{~g} / \mathrm{L}$ yeast extract, and volume completed to $1 \mathrm{~L}$ with distilled water. The following substrates $(0.5 \% \mathrm{w} / \mathrm{v})$ were added to the medium: carboxymethylcellulose (CMC) (SigmaAldrich, St. Louis, MO, USA) was used for the initial screening of cellulase-positive endophytes; $\mathrm{PH}$ or SD was used for comparison to CMC. Negative control consisted of liquid medium incubated without fungal inoculation. Flasks were incubated in triplicate, at $28 \pm 2^{\circ} \mathrm{C}$, for $168 \mathrm{~h}$ under stationary condition and filtered with sterile gauze to separate the fungal mycelia. Cell-free supernatants were used as crude enzymatic extracts.

\section{Cup plate assay \\ Crude enzymatic extracts were inoculated} $(50 \mu \mathrm{L})$ on Petri dishes containing CMC-agar medium $\left(18 \mathrm{~g} / \mathrm{L}\right.$ agar, $10 \mathrm{~g} / \mathrm{L}$ CMC, $0.1 \mathrm{M} \mathrm{Na}^{+}$ acetate buffer, $\mathrm{pH}$ 5.0) with the surface perforated for cup plates (6-mm diameter). Positive control consisted of commercial cellulase from Aspergillus niger (powder, off-white, $\sim 0.8 \mathrm{U} / \mathrm{mg}$ ) purchased from Sigma-Aldrich (St. Louis, MO, USA). The experiment was performed in triplicate and dishes were incubated at $28 \pm 2^{\circ} \mathrm{C}$ for $24 \mathrm{~h}$. The dishes were flooded with $0.1 \%$ Congo red solution (in $0.1 \mathrm{M}$ Tris buffer $\mathrm{pH}$ 8.0) for $30 \mathrm{~min}$ and de-stained with $0.5 \mathrm{NaCl}$ solution (in $0.1 \mathrm{M}$ Tris buffer $\mathrm{pH}$ 8.0) for $15 \mathrm{~min}$. Cellulase activity was evaluated by the 
development of colorless halos on a red background and measured in millimeters.

\section{Endoglucanase activity assay}

A modified version of the carboxymethylcellulase assay for endo- $\beta-1,4-$ glucanase described by Ghose (1987) was used. The $0.5 \mathrm{~mL}$-aliquots of crude enzymatic extracts were pipetted into test tubes triplicates containing $0.5 \mathrm{~mL}$ of CMC solution $(1 \% \mathrm{w} / \mathrm{v})$ in sodium citrate buffer (50 mM; pH 4.8). After 15 and $30 \mathrm{~min}$ of incubation at $40^{\circ} \mathrm{C}, 1 \mathrm{~mL}$ of 3,5-dinitrosalicylic acid (DNS) (MILLER et al., 1959) was added. Tubes remained at $100^{\circ} \mathrm{C}$ for $5 \mathrm{~min}$ and immediately transferred to a cold-water bath. The volume of each tube was completed to $3 \mathrm{~mL}$ with distilled water.

Blank tubes in each assay contained crude enzymatic extracts and CMC solution (1\% w/v), which were immediately mixed to DNS (corresponding to time zero). Absorbance was measured in a Libra S60PC spectrophotometer (Biochrom, Cambourne, CBE, UK) at $540 \mathrm{~nm}$. One unit of endoglucanase was the amount of enzyme required to liberate $1 \mu \mathrm{mol} / \mathrm{min} / \mathrm{mL}$ glucose.

\section{Statistical analyses}

To compare the best culture medium for the enzymatic production by each fungus and the best fungal producer by submerged fermentation in each culture medium, results of cup plate and endoglucanase activity assays were analyzed by ANOVA (analysis of variance) and means were compared by Tukey test $(\mathrm{p}<0.05)$ with SISVAR 5.3 (FERREIRA, 2011).

\section{RESULTS AND DISCUSSION}

\section{Screening of cellulase-positive endophytes}

Cellulose is the most abundant renewable carbon source on the Earth's crust. In nature, microorganisms degrade cellulose by cellulase production. In fact, enzymes from filamentous fungi are the most efficient cellulose-degrading tools (GUTIÉRREZ-ROJAS et al., 2015). Consequently, fungal sources of enzymes were initially screened by the cup plate assay, where halo formations revealed that the inducing substrate was hydrolyzed by microbial cellulases. Table 1 shows that eight fungal endophytes (belonging to genera Cochliobolus, Diaporthe, Fusarium and Phoma) produced cellulolytic enzymes when grown on CMC medium. Alternaria and Bipolaris strains did not have positive results. Since fungal metabolic activity is affected by nutritional and physical parameters, the $V$. labrusca endophytes should be further evaluated according to their capacity for the production of cellulase with different cultivation condition.

Table 1. Screening of cellulase-positive endophytes using carboxymethyl cellulose (CMC) as carbon source for submerged fermentation. Results of cup plate assay are given as mean \pm standard deviation.

\begin{tabular}{lll}
\hline Endophytic fungi/ Controls & Host plants & Halos $(\mathbf{m m})$ \\
\hline Diaporthe sp. KM362368 & $\mathrm{B}$ & $15.5 \pm 0.07^{\mathrm{b}}$ \\
Fusarium culmorum KM362384 & $\mathrm{C}$ & $15.1 \pm 0.04^{\mathrm{b}}$ \\
Diaporthe sp. KM362392 & $\mathrm{C}$ & $15.0 \pm 0.05^{\mathrm{b}}$ \\
Diaporthe sp. KM362378 & $\mathrm{B}$ & $13.5 \pm 0.02^{\mathrm{c}}$ \\
Phoma sp. KM362379 & $\mathrm{B}$ & $12.4 \pm 0.02^{\mathrm{d}}$ \\
Cochliobolus sp. KM362367 & $\mathrm{B}$ & $11.9 \pm 0.06^{\mathrm{de}}$ \\
Diaporthe sp. KM362382 & $\mathrm{B}$ & $11.1 \pm 0.03^{\mathrm{ef}}$ \\
Phoma sp. KM362373 & $\mathrm{B}$ & $10.8 \pm 0.02^{\mathrm{f}}$ \\
Bipolaris sp. KM362374 & $\mathrm{B}$ & $00.0 \pm 0.00^{\mathrm{g}}$ \\
Fusarium sp. KM362390 & $\mathrm{C}$ & $00.0 \pm 0.00^{\mathrm{g}}$ \\
Bipolaris sp. KM362380 & $\mathrm{B}$ & $00.0 \pm 0.00^{\mathrm{g}}$ \\
Alternaria sp. KM362386 & $\mathrm{C}$ & $00.0 \pm 0.00^{\mathrm{g}}$ \\
Alternaria alternata KM362389 & $\mathrm{C}$ & $00.0 \pm 0.00^{\mathrm{g}}$ \\
Cochliobolus sp. KM362388 & $\mathrm{C}$ & $00.0 \pm 0.00^{\mathrm{g}}$ \\
Positive control & - & $25.8 \pm 0.02^{\mathrm{a}}$ \\
Negative control & - & $00.0 \pm 0.00^{\mathrm{g}}$ \\
\hline
\end{tabular}

Means of triplicates followed by different letters are significantly different by Tukey test $(\mathrm{p}<0.05)$. Host plants: Bordô (B) or Concord (C) cultivars of Vitis labrusca. Positive control: cellulase from Aspergillus niger (powder, off-white, 0.8 U/mg; Sigma-Aldrich) diluted $(1 \mathrm{mg} / \mathrm{mL})$ in distilled water. Negative control: liquid medium incubated without fungal inoculation. 
ANOVA showed statistically significant differences among the enzymatic halos, ranging between 10.8 and $15.5 \mathrm{~mm}$ in diameter; the highest rates were obtained for Diaporthe sp. KM362368 $(15.5 \pm 0.07 \mathrm{~mm})$, Fusarium culmorum KM362384 $(15.1 \pm 0.04 \mathrm{~mm})$, Diaporthe sp. KM362392 $(15.0 \pm 0.05 \mathrm{~mm})$ and Diaporthe sp. KM362378 $(13.5 \pm 0.02 \mathrm{~mm})$. Therefore, enzymatic production of the fungal strains was subsequently evaluated using agro-industrial wastes as substrates.

\section{Comparison of the influence of different substrates on enzymatic activity}

Cellulases may be produced by microorganisms on cheap lignocellulosic substrates (SRIDEVI et al., 2015). SD contains approximately $48 \%$ cellulose, $17 \%$ hemicellulose and $12 \%$ lignin (SRIDEVI et al., 2015), while PH contains about $39 \%, 23 \%$ and $21 \%$ cellulose, hemicellulose and lignin, respectively (CHUWECH; RAKARIYATHAM, 2014). In Brazil, the abovementioned substrates are agro-industrial wastes and represent low-cost raw materials, which may be used to produce value-added compounds such as enzymes.

After the initial screening, CMC and agroindustrial wastes (PH and SD) were compared by the cup plate and endoglucanase activity assays (Table 2). Enzymes used for producing plant-based ethanol (i.e., bioethanol) have gained more importance in recent years, including endoglucanases (YENNAMALLI et al., 2013). Therefore, among the cellulases, it was chosen to be quantified by the endoglucanase activity assay. Table 2 shows that three Diaporthe (= Phomopsis) endophytes were the best sources of endoglucanase. A recent study has also highlighted Diaporthe anacardii PL01 (with halos measuring $15.02 \mathrm{~mm}$ and $1.60 \mu \mathrm{mol} / \mathrm{min}$ of endoglucanase activity) and Diaporthe sp. PL67 $(12.89 \mathrm{~mm}$ and $1.23 \mu \mathrm{mol} / \mathrm{min})$ as the best enzymatic sources (RIBEIRO et al., 2018). The genus occurs as plant pathogens, endophytes or saprobes (GOMES et al., 2013) and plays an important role in decomposition in plant senescence (CARROLL; PETRINI, 1983), related to their lignocellulolytic activity (JORDAAN et al., 2006).

Table 2. Effect of different carbon sources on enzymatic activity of endophytic fungi, evaluated by cup plate (halos in $\mathrm{mm}$ ) and endoglucanase activity assays $(\mu \mathrm{mol} / \mathrm{min}$ ). Results are given as means of triplicates \pm standard deviation.

\section{Fungi/ Controls \\ Controls}

Diaporthe sp. KM362392

Diaporthe sp. KM362368

Diaporthe sp. KM362378

F. culmorum KM362384

Positive control

Negative control

\begin{abstract}
Diaporthe sp. KM362392
Diaporthe sp. KM362368

Diaporthe sp. KM362378

F. culmorum KM362384
\end{abstract}

Inducer substrates

$\begin{array}{lll}\text { CMC } & \text { PH } & \text { SD }\end{array}$

$\begin{array}{lcl}\text { Halo degradation (mm) } & \\ 16.1 \pm 0.01^{\mathrm{Ab}} & 14.5 \pm 0.01^{\mathrm{Bb}} & 14.7 \pm 0.03^{\mathrm{Bb}} \\ 15.7 \pm 0.03^{\mathrm{Ab}} & 14.1 \pm 0.06^{\mathrm{Bb}} & 12.0 \pm 0.03^{\mathrm{Cc}} \\ 14.3 \pm 0.01^{\mathrm{Ac}} & 00.0 \pm 0.00^{\mathrm{Bc}} & 00.0 \pm 0.00^{\mathrm{Bd}} \\ 13.7 \pm 0.08^{\mathrm{Ac}} & 00.0 \pm 0.00^{\mathrm{Bc}} & 00.0 \pm 0.00^{\mathrm{Bd}} \\ 25.7 \pm 0.06^{\mathrm{a}} & 25.7 \pm 0.06^{\mathrm{a}} & 25.7 \pm 0.06^{\mathrm{a}} \\ 00.0 \pm 0.00^{\mathrm{d}} & 00.0 \pm 0.00^{\mathrm{c}} & 00.0 \pm 0.00^{\mathrm{d}}\end{array}$

\section{Endoglucanase activity ( $\mu \mathrm{mol} / \mathrm{min})$}

$\begin{array}{lll}3.52 \pm 0.98^{\mathrm{Aa}} & 2.93 \pm 0.23^{\mathrm{Aa}} & 3.26 \pm 0.38^{\mathrm{Aa}} \\ 3.14 \pm 0.09^{\mathrm{Aab}} & 1.57 \pm 0.15^{\mathrm{Bb}} & 1.15 \pm 0.02^{\mathrm{Cb}} \\ 2.65 \pm 0.24^{\mathrm{Aa}} & 0.63 \pm 0.15^{\mathrm{Bb}} & 0.57 \pm 0.07^{\mathrm{Bb}} \\ 2.05 \pm 0.24^{\mathrm{Aa}} & 0.63 \pm 0.12^{\mathrm{Bb}} & 0.73 \pm 0.10^{\mathrm{Bb}}\end{array}$

Means followed by different lower-case letters (columns) or upper-case letters (rows) are significantly different by Tukey test ( $\mathrm{p}<0.05)$. Inducer substrates: CMC (carboxymethylcellulose), PH (peanut hull) and SD (sawdust). Positive control: cellulase from Aspergillus niger (powder, off-white, $\sim 0.8 \mathrm{U} / \mathrm{mg}$; Sigma-Aldrich) diluted $(1 \mathrm{mg} / \mathrm{mL})$ in distilled water. Negative control: liquid medium incubated without fungal inoculation.

ANOVA showed that CMC, $\mathrm{PH}$ and SD were similarly efficient for Diaporthe sp. KM362392, with results varying between $3.52 \pm 0.98$ and $2.93 \pm 0.23 \mu \mathrm{mol} / \mathrm{min}$. On the other hand,
Diaporthe strains showed the highest activities when grown on $\mathrm{CMC}(\mathrm{CMC}>\mathrm{PH} \geq \mathrm{SD}): 3.14 \pm 0.09$ and $2.65 \pm 0.24 \mu \mathrm{mol} / \mathrm{min}$, respectively for Diaporthe sp. KM362368 and KM362378. The fungal 
biosynthesis is a strain-dependent process and may foreground the differences in compounds secreted by closely related species cultivated under the same conditions (DIAMANTOPOULOU et al., 2014), as observed in our study for these Diaporthe strains. In corroboration, marked differences were already reported for other metabolic products obtained for endophytes from this genus (ORLANDELLI et al., 2016, 2017b). CMC was also the most suitable substrate for the endoglucanase activity of $F$. culmorum, where rate $(2.05 \pm 0.24 \mu \mathrm{mol} / \mathrm{min})$ was statistically higher than that for other substrates.

PH is scantily employed for cellulase production. Results highlighted Diaporthe sp. KM362392 $(2.93 \pm 0.23 \mu \mathrm{mol} / \mathrm{min})$ and Diaporthe sp. KM362368 $(1.57 \pm 0.15 \mu \mathrm{mol} / \mathrm{min})$ with the highest endoglucanase activity when $\mathrm{PH}$ was used as substrate. When grown under submerged fermentation with $\mathrm{PH}, A$. niger and Humicola insolens had enzymatic production of $0.54 \mathrm{U} / \mathrm{mL}$ (MOHITE; MAGAR, 2010) and $1.0 \mathrm{U} / \mathrm{L}$ (BORKAR; THAKRE, 2014), respectively.

In the case of SD, the four endophytes showed differences in enzymatic activities, with means ranging between $0.57 \pm 0.07$ and $3.26 \pm 0.38$ $\mu \mathrm{mol} / \mathrm{min}$. Highest rate was observed for Diaporthe sp. KM362392. These enzymatic activities are superior to that (approximately $0.07 \mathrm{IU} / \mathrm{mL}$ ) obtained for the submerged cultivation of Aspergillus flavus in a bioreactor with alkaline pretreated SD (OJUMU et al., 2003) and for the enzymatic hydrolysis of alkaline pretreated SD by A. niger (approximately $0.18 \mathrm{U} / \mathrm{mL}$ ) (ACHARYA et al., 2008).

\section{CONCLUSIONS}

Some V. labrusca endophytes may produce endoglucanase from agro-industrial wastes, with Diaporthe isolates as promising enzymatic sources. Diaporthe sp. KM362392 produced statistically similar amount of endoglucanase with carboxymethylcellulose, peanut hull or sawdust.

Current investigation contributes towards the reuse of agro-industrial wastes abundantly generated in Brazil. Further investigations should be undertaken to increase the enzymatic production by using the wastes tested.

\section{ACKNOWLEDGMENTS}

The authors are grateful to Conselho Nacional de Desenvolvimento Científico e Tecnológico (CNPq; 311534/2014-7 and 447265/2014-8) and Fundação Araucária (276/2014) for financial support. A.C. Felber thanks Fundação Araucária and Coordenação de Aperfeiçoamento de Pessoal de Nível Superior (CAPES) for the doctoral scholarship.

RESUMO: Endoglucanases são enzimas amplamente empregadas em diferentes setores industriais; embora sua produção apresente custos elevados. Estudos sobre novas fontes microbianas e substratos mais baratos são de grande importância, incluindo os resíduos agroindustriais. Nesse estudo, casca de amendoim (CA) e serragem (SE) foram testadas como substratos para o cultivo submerso de 14 fungos endofíticos isolados das cultivares Bordô e Concord de videira (Vitis labrusca L.) Os endófitos foram crescidos em meio contendo carboximetilcelulose (CMC) e o ensaio cup plate mostrou resultados positivos para oito fungos (pertencentes aos gêneros Cochliobolus, Diaporthe, Fusarium and Phoma); os halos enzimáticos variaram entre

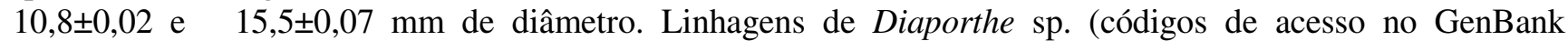
KM362392, KM362368 e KM362378) e Fusarium culmorum KM362384 se destacaram como produtores mais promissores. Então, o uso de CA e SE como substratos para a fermentação desses fungos foi avaliado pelo ensaio cup plate e pela quantificação da atividade de endoglucanase. Os maiores halos enzimáticos foram

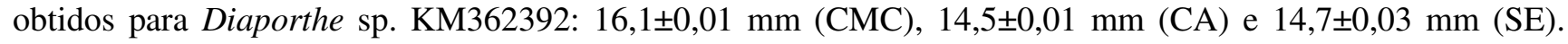
Esse fungo também apresentou os maiores níveis de endoglucanase: a análise de variância revelou que CMC $(3,52 \pm 0,98 \mu \mathrm{mol} / \mathrm{min})$, CA $(2,93 \pm 0,23 \mu \mathrm{mol} / \mathrm{min})$ e $\mathrm{SE}(3,26 \pm 0,38 \mu \mathrm{mol} / \mathrm{min})$ foram substratos similarmente eficientes. Esses resultados expandem o conhecimento sobre endófitos de V. labrusca que são fontes de endoglucanases; futuras otimizações quanto ao cultivo submerso com CA e SE podem ser utilizadas para aumentar a produção enzimática a partir do uso desses resíduos.

PALAVRAS-CHAVE: Celulase. Enzimas microbianas. Endófitos. Resíduos agroindustriais. Fermentação submersa. 


\section{REFERENCES}

ACHARYA, P. B.; ACHARYA, D. K.; MODI, H. A. Optimization for cellulase production by Aspergillus niger using saw dust as substrate. African Journal of Biotechnology, Nairobi-Lagos, v. 7, n. 22, p. 4147-4152, 2008.

BEZERRA, J. D. P.; NASCIMENTO, C. C. F.; BARBOSA, R. N.; SILVA, D. C. V.; SVEDESE, V. M.; SILVA-NOGUEIRA, E. B.; GOMES, B. S.; PAIVA, L. M.; SOUZA-MOTTA, C. M. Endophytic fungi from medicinal plant Bauhinia forficata: diversity and biotechnological potential. Brazilian Journal of Microbiology, São Paulo, v. 46, n. 1, p. 49-57, 2015. https://doi.org/10.1590/s1517-838246120130657

BORKAR, K. M.; THAKRE, R. P. Effect of temperature, $\mathrm{pH}$ and substrates on CMCase enzyme activity of thermophilic fungus Humicola insolens. International Journal of Life Sciences, Maharashtra, n. A2, p. 91-94, 2014.

CARROLL, G.; PETRINI, O. Patterns of substrate utilization by some fungal endophytes from coniferous foliage. Mycologia, New York, v. 75, n. 1, p. 53-63, 1983. https://doi.org/10.1080/00275514.1983.12021637

CHRISTAKOPOULOS, P.; KEKOS, D.; KOLISIS, F.; MACRIS, B. J. Controlling simultaneous production of endoglucanase and beta-glucosidase by Fusarium oxysporum in submerged culture. Biotechnology Letters, Dordrecht, v. 17, n. 8, p. 883-88, 1995. https://doi.org/10.1007/bf00129023

CHUWECH, M.; RAKARIYATHAM, N. Potential of peanut hulls as substrates for fungal cellulase bioproduction through solid state fermentation. Asia-Pacific Journal of Science and Technology, Khon Kaen, v. 19, p. 235-243, 2014.

DIAMANTOPOULOU, P.; PAPANIKOLAOU, S.; KOMAITIS, M.; AGGELIS, G.; PHILIPPOUSSIS, A. Patterns of major metabolites biosynthesis by different mushroom fungi grown on glucose-based submerged cultures. Bioprocess Biosystems Engineering, Berlin-Heidelberg, v. 37, n. 7, p. 1385-1400, 2014.

https://doi.org/10.1007/s00449-013-1112-2

DUTTA, D.; PUZARI, K. C.; GOGOI, R.; DUTTA, P. Endophytes: exploitation as a tool in plant protection. Brazilian Archives of Biology and Technology, Curitiba, v. 57, n. 5, p. 621-629, 2014.

https://doi.org/10.1590/s1516-8913201402043

ELISASHVILI, V. Submerged cultivation of medicinal mushrooms: bioprocesses and products. International Journal of Medicinal Mushrooms, New York, v. 14, n. 3, p. 211-239, 2012.

https://doi.org/10.1615/intjmedmushr.v14.i3.10

FELBER, A. C.; ORLANDELLI, R. C.; RHODEN, A. S.; GARCIA, A.; COSTA, A. T.; AZEVEDO, J. L.; PAMPHILE, J. A. Bioprospecting foliar endophytic fungi of Vitis labrusca Linnaeus, Bordô and Concord cv. Annals of Microbiology, Milan, v. 66, n. 2, p. 765-775, 2016. https://doi.org/10.1007/s13213-015-1162-6

FERREIRA, D. F. Sisvar: a computer statistical analysis system. Ciência e Agrotecnologia, Lavras, v. 35, n. 6, p. 1039-1042, 2011. https://doi.org/10.1590/s1413-70542011000600001

FOOD AND AGRICULTURE ORGANIZATION OF THE UNITED NATIONS. FaoSatat 2014. Available at: <http://faostat3.fao.org/download/Q/QC/E>. Acessed in: 25 Mar. 2016.

FOUDA, A. H.; HASSAN, S. E.-D.; EID, A. M.; EWAIS, E. E.-D. Biotechnological applications of fungal endophytes associated with medicinal plant Asclepias sinaica (Bioss.). Annals of Agricultural Sciences, Cairo, v. 60, n. 1, p. 95-104, 2015. https://doi.org/10.1016/j.aoas.2015.04.001

GHOSE, T. K. Measurement of cellulase activities. Pure and Applied Chemistry, Oxford, v. 59, n. 2, p. 257268, 1987. https://doi.org/10.1351/pac198759020257 
GOMES, R. R.; GLIENKE, C.; VIDEIRA, S. I.; LOMBARD, L.; GROENEWALD, J. Z.; CROUS, P. W. Diaporthe: a genus of endophytic, saprobic and plant pathogenic fungi. Persoonia, Leiden, v. 31, p. 1-41, Mar. 2013. https://doi.org/10.3767/003158513x666844

GUTIÉRREZ-ROJAS Mecanismos y regulación de la hidrólisis enzimática de celulosa en hongos filamentosos: casos clásicos y nuevos modelos. Revista Iberoamericana de Micología, Madrid, v. 32, n. 1, p. 1-12, 2015. https://doi.org/10.1016/j.riam.2013.10.009

JORDAAN, A.; TAYLOR, J. E.; ROSSENKHAN, R. Occurrence and possible role of endophytic fungi associated with seed pods of Colophospermum mopane (Fabaceae) in Botswana. South African Journal of Botany, Pretoria, v. 72, n. 2, p. 245-255, May 2006. https://doi.org/10.1016/j.sajb.2005.09.007

LIN, L.; LIU, X.; ZHOU, Y.; GUAN, L.; HE, J.; HUANG, W. A novel pH-stable, endoglucanase (JqCel5A) isolated from a salt-lake microorganism, Jonesia quinghaiensis. Electronic Journal of Biotechnology, Valparaiso, v. 24, p. 56-62, 2016. https://doi.org/10.1016/j.ejbt.2016.09.004

LUMYONG, S.; LUMYONG, P.; MCKENZIE, E. H. C.; HYDE, K. D. Enzymatic activity of endophytic fungi of six native seedling species from Doi Suthep-Pui National Park, Thailand. Canadian Journal of Microbiology, Ottawa, v. 48, n. 12, p. 1109-1112, 2002. https://doi.org/10.1139/w02-112

LYND, L. R.; WEIMER P. J.; VAN ZYL H. W.; PRETORIUS, I. S. Microbial cellulose utilization: fundamentals and biotechnology. Microbiology and Molecular Biology Reviews, Washington, v. 66, n. 3, p. 506-577, 2002. https://doi.org/10.1128/mmbr.66.3.506-577.2002

MANACHINI, P. L.; FORTINA, M. G.; PARINI, C. Purification and properties of an endopolygalacturonase produced by Rhizopus stolonifer. Biotechnology Letters, Dordrecht, v. 9, n. 3, p. 219-224, 1987. https://doi.org/10.1007/bf01024570

McKELVEY, S. M.; MURPHY, R. A. Biotechnological use of fungal enzymes. In: KAVANAGH, K. (Ed). Fungi: biology and applications. $2^{\text {nd }}$ ed. New Delhi: Wiley Online Library, 2011, p. 179-204. https://doi.org/10.1002/9781119976950.ch7

MILLER, G. L. Use of dinitrosalicylic acid reagent for determination of reducing sugar. Analytical Chemistry, Washington, v. 31, n. 3, p. 426-428, 1959. https://doi.org/10.1021/ac60147a030

MOHITE, B. V.; MAGAR, J. G. Use of agricultural wastes for cellulases production by Aspergillus niger with submerged and solid state fermentation. Bionano Frontier, Navi Mumbai, v. 3, n. 2, p. 189-192, 2010.

OJUMU, T. V.; SOLOMONM, B. O.; BETIKU, E.; LAYOKUN, S. K.; AMIGUN, B. Cellulase production by Aspergillus flavus Linn Isolate NSPR 101 fermented in sawdust, bagasse and corncob. African Journal of Biotechnology, Nairobi-Lagos, v. 2, n. 6, p. 150-152, 2003. https://doi.org/10.5897/ajb2003.000-1030

ORLANDELLI, R. C.; ALMEIDA, T. T.; ALBERTO, R. N.; POLONIO, J. C.; AZEVEDO, J. L.; PAMPHILE, J. A. Antifungal and proteolytic activities of endophytic fungi isolated from Piper hispidum Sw. Brazilian Journal of Microbiology, São Paulo, v. 46, n. 2, p. 359-366, 2015. https://doi.org/10.1590/s1517838246220131042

ORLANDELLI, R. C.; VASCONCELOS, A. F. D.; AZEVEDO, J. L.; CORRADI DA SILVA, M. L.; PAMPHILE, J. A. Screening of endophytic sources of exopolysaccharides: preliminary characterization of crude exopolysaccharide produced by submerged culture of Diaporthe sp. JF766998 under different cultivation time. Biochimie Open, Amsterdam, v. 2, p. 33-40, 2016. https://doi.org/10.1016/j.biopen.2016.02.003 
ORLANDELLI, R. C.; SANTOS, M. S.; POLONIO, J. C.; AZEVEDO, J. L.; PAMPHILE, J. A. Use of agroindustrial wastes as substrates for $\alpha$-amylase production by endophytic fungi isolated from Piper hispidum Sw. Acta Scientiarum. Technology, Maringá, v. 39, n. 3, p. 255-261, 2017a. https://doi.org/10.4025/actascitechnol.v39i3.30067

ORLANDELLI, R. C.; CORRADI DA SILVA, M. L.; VASCONCELOS, A. F. D.; ALMEIDA, I. V.; VICENTINI, V. E. P.; PRIETO, A. C.; HERNANDEZ, M. D. D.; AZEVEDO, J. L.; PAMPHILE, J. A. $\beta$ $(1 \rightarrow 3,1 \rightarrow 6)$-D-glucans produced by Diaporthe sp. endophytes: purification, chemical characterization and antiproliferative activity against MCF-7 and HepG2-C3A cells. International Journal of Biological Macromolecules, Amsterdam, v. 94, p. 431-437, 2017b. https://doi.org/10.1016/j.ijbiomac.2016.10.048

PENG, X. W.; CHENG, H. Z. Microbial oil accumulation and cellulase secretion of the endophytic fungi from oleaginous plants. Annals of Microbiology, Milan, v. 57, n. 2, p. 239-242, 2007.

https://doi.org/10.1007/bf03175213

RIBEIRO, A. S.; POLONIO, J. C.; COSTA, A. T.; SANTOS, C. M.; RHODEN, S. A.; AZEVEDO, J. L.; PAMPHILE, J. A. Bioprospection of culturable endophytic fungi associated with the ornamental plant Pachystachys lutea. Current Microbiology, New York, v. 75, n. 5, p. 588-596, 2018.

https://doi.org/10.1007/s00284-017-1421-9

RODRIGUEZ, R. J.; WHITE JR, J. F.; ARNOLD, A. E.; REDMAN, R. S. Fungal endophytes: diversity and functional roles. New Phytology, Oxford, v. 182, n. 2, p. 314-330, 2009. https://doi.org/10.1111/j.14698137.2009.02773.x

SINGHANIA, R. R.; BINOD, P.; PATEL, A. K. Advances in lignocellulosic bioethanol. In: YANG, S.; ELENSASHY, H.; THONGCHUL, N. Bioprocessing technologies in biorefinery for sustainable production of fuels, chemicals, and polymers. John Wiley \& Sons, 488 p. https://doi.org/10.1002/9781118642047.ch11

SMITH, D.; ONIONS, A. H. S. The preservation and maintenance of living fungi. Norwick: Page Bros, 1983.

STONE, J. K.; BACON, C. W.; WHITE, J. F. An overview of endophytic microbes: endophytism defined. In: BACON, C. W.; WHITE, J. F. (Ed.). Microbial endophytes. New York: Marcel Dekker Inc, 2000. p 3-30.

SRIDEVI, A.; NARASIMHA, G.; RAMANJANEYULU, G.; DILEEPKUMAR, K.; RAJASEKHAR, R. B.; SUVARNALATHA DEVI, P. Saccharification of pretreated sawdust by Aspergillus niger cellulase. 3 Biotech, Berlin, v. 5, n. 6, p. 883-892, 2015. https://doi.org/10.1007/s13205-015-0284-7

YENNAMALLI, R. M.; RADER, A. J.; KENNY, A. J.; WOLT, J. D.; SEN, T. Z. Endoglucanases: insights into thermostability for biofuel applications. Biotechnology for Biofuels, London, v. 6, n. 1, p. 1-9, 2013. https://doi.org/10.1186/1754-6834-6-136 